\title{
Historical Perspectives on the Behavioral Function of the Insula
}

\author{
Philip Gerard Gasquoine ${ }^{1}$
}

Received: 27 April 2015 / Accepted: 29 April 2015 /Published online: 10 May 2015

(C) Springer Science+Business Media New York 2015

The advent of functional neuroimaging technology has seen increased interest in the behavioral function of the region of cerebral cortex known as the insula. Localization of function for this brain region has been slow to develop as it is rarely affected in isolation by naturally occurring structural brain injury and many of the behaviors with which it has been associated are not measured by traditional neuropsychological tests. While it is widely acknowledged that the name originated with Johann-Christian Reil (1809), who is more famous for coining the term "psychiatry" (Binder et al. 2007) little has been written in the English language literature of historical conceptions of the function of insular cortex. One exception was the pioneering electrical stimulation study of patients treated surgically for focal seizures originating within or near insular cortex at the Montreal Neurological Institute (Penfield and Faulk 1955) that noted: "Early anatomists and physiologists regarded it diversely as a center for speech (Rose 1928), or for taste (von Bechterew 1899)" (p. 445).

Both references are to papers published in German. Rose (1928) was a comparative cytoarchitectonic study of insular cortex in several species including the bat, hedgehog, lemur, baboon, and human. It is known for the identification of so-called von Economo neurons in the insula (Ŝimić and Hof 2015). In contrast, the reference to von Bechterew (1899) is incorrect. As clarified by Sörös (This issue), the early conception of the insula as primary taste cortex should be credited to Gorschkow (1901) who conducted ablation studies on dogs in Bechterew's laboratory. Primary taste cortex remains the behav- ioral function most commonly attributed to the insula in modern neuroscience textbooks (e.g., Kolb and Whishaw 2014), even though this brain region is now considered to play a much more diverse role in human behavior (Gasquoine 2014).

\section{References}

Binder, D. K., Schaller, K., \& Clasmann, H. (2007). The seminal contributions of Johann-Christian Reil to anatomy, physiology, and psychiatry. Neurosurgery, 61, 1091-1096.

Gasquoine, P. G. (2014). Contributions of the insula to cognition and emotion. Neuropsychology Review, 24, 77-87.

Gorschkow, J. P. (1901). Ueber die Localisation des Geruchscentra in der Hirnrinde. Monatsschrift für Psychiatrie und Neurologie, 10, 469. http://www.karger.com/Article/Pdf/221046. Accessed 24 Apr 2015.

Kolb, B., \& Whishaw, I. Q. (2014). An introduction to brain and behavior (4th ed.). NY: Worth Publishers.

Penfield, W., \& Faulk, M. E., Jr. (1955). The insula: further observations on its function. Brain, 78, 445-470.

Reil, J. C. (1809). Die sylvische Grube. Archiv für die Physiologie, 9, 195-208.

Rose, M. (1928). Die inselrinde des menschen und der tiere. Journal für Psychologie und Neurologie, 37, 470-624.

Simić, G., \& Hof, P. R. (2015). In search of the definitive Brodmann's map of cortical areas in human. Journal of Comparative Neurology, $523,5-14$.

Sörös, P. (This issue). Early research on the localization of the primary gustatory cortex. Neuropsychology Review.

von Bechterew, W. (1899). Untersuchungsevgebrisse betreffend die Erregbarkeit des hinteren Abschrittes des Hirnlappens. Archiv für Anatomie und Physiologie, Leipzig, 500-503.
Philip Gerard Gasquoine

drgdrg13@yahoo.com

1 Department of Psychology, University of Texas - Pan American, 1201 W. University Drive, Edinburg, Texas 78541, USA 